\title{
Protective hepatitis B surface antibody (Anti-HBs) levels among health care workers in Duhok city of Iraq
}

\author{
Sagvan Hasan Alia, Bakhtiyar Ahmed Rasheed b, Tariq Salman Al-Hadithi c
}

\author{
a M.B.Ch.B, FKBMS (CM)., Directorate of preventive affairs, Duhok directorate general of Health, Duhok- \\ Iraq \\ ${ }^{b}$ M.B.Ch.B, M.Sc., Directorate of preventive affairs, Duhok directorate general of Health, Duhok-Iraq \\ c M.B.Ch.B, DTM\&H, MSc, PhD, FFPH, FRCP., Department of community medicine, college of medicine, \\ Hawler Medical University, Erbil- Iraq.
}

Submitted date: 01.03.2018, Accepted date: 14.07.2018

\begin{abstract}
Objective: This cross sectional study aimed to find the prevalence of protective hepatitis B surface antibodies (anti-HBs) and HBV infection among health care workers in Duhok city. Method: In this cross sectional study, 504 health care workers from Duhok city were studied. The data requested included some demographics and risk factors of exposure. Blood samples were tested for HBsAg, anti-HBc and anti-HBs by enzyme-linked immunosorbent assay (ELISA). Results: The prevalence of protective anti-HBs was higher among vaccinated participants $(\mathrm{p}<0.001)$ and was positively associated with the number of vaccine doses $(\mathrm{p}<0.001)$. Around $60.0 \%$ of participants had received at least one dose of vaccine and $38 \%$ were fully vaccinated. Prevalence of post-vaccination anti-HBs testing among fully vaccinated participants was $26.7 \%$. The rate of protective anti-HBs levels among fully vaccinated participants was $84.8 \%$. The rates of HBsAg and overall HBV infection were $1.8 \%$, and $9.5 \%$ respectively. HBV infection was significantly associated with occupational exposure to blood (OR=2.38; 95\% $\mathrm{CI}=1.26-4.50)$ and dental interventions $(\mathrm{OR}=2.36$; $95 \% \mathrm{CI}=1.25-4.46)$. Conclusion: The rate of protective anti- $\mathrm{HBs}$ level among fully vaccinated HCWs is acceptable. Vaccination coverage and post-vaccination testing are still low and there is no post-exposure prophylaxis policy in Duhok health care facilities.
\end{abstract}

Key words: Hepatitis B virus, Hepatitis B antibodies, Hepatitis B vaccines, health personnel, Iraq Corresponding Author: Tariq Salman Al-Hadithi, Department of community medicine, college of medicine, Hawler Medical University, Erbil-IRAQ Gsm: +9647504360411 E-mail: talhadithi@yahoo.com

\section{Copyright holder Turkish Journal of Public Health}

This work is licensed under a Creative Commons Attribution-NonCommercial 4.0 International License. $(\mathrm{cc}) \mathrm{EY}-\mathrm{NC}$ 


\title{
Irak'ın Duhok şehrinde sağlık çalışanları arasında koruyucu hepatit B yüzey antikoru (Anti-HBs) düzeyleri
}

Özet

\begin{abstract}
Amaç: Bu çalışma Duhok şehrinde sağlık çalışanları arasında koruyucu hepatit B yüzey antikorlarının (anti-HBs) ve HBV enfeksiyonunun yaygınlığının saptanması amacıyla yapılmıştır. Yöntem: Bu kesitsel çalışmaya, Duhok kentinden 504 sağlık çalışanı katılmıştır. Toplanan veriler, katılanların bazı demografik özellikleri ile risk faktörlerini içermektedir. Kan örnekleri ELISA ile HBsAg, anti-HBc ve anti-HBs için test edilmiştir. Bulgular: Anti-HBs prevalansı, aşılanan katılımcılar arasında daha yüksekti $(\mathrm{p}<0.001)$ ve aşı doz sayısı ile pozitif ilişkiliydi ( $\mathrm{p}<0.001)$. Katılımcıların yaklaşık \%60.0'ı en az bir doz aşı almış ve \%38'i tamamen aşılanmıştır. Tamamen aşılanmış katılımcılar arasında aşılama sonrası anti-HBs testi oranı \%26.7 idi. Tamamen aşılanmış katılımcılar arasında anti-HBs oranı \%84.8 idi. HBsAg ve genel HBV enfeksiyonu oranları sırasiyla \%1.8 ve \%9.5 idi. HBV enfeksiyonu, kan ile mesleki maruziyet durumunda $(\mathrm{OR}=2.38 ; \% 95 \mathrm{CI}=1.26-4.50)$ ve diş müdahaleleri ile anlamlı derecede ilişkiliydi $(\mathrm{OR}=2.36$; \%95 CI= 1.25-4.46). Sonuç: Tamamen aşılanmış sağlık çalışanları arasında koruyucu anti-HBs oranı kabul edilebilir düzeydedir. Aşılama ve aşılama sonrası test oranları hala düşüktür ve Duhok sağlık tesislerinde maruziyet sonrası profilaksi yoktur.
\end{abstract}

Anahtar kelimeler: Hepatit B virusu, Hepatitis B antikoru, Hepatit B aşısı, sağlık personeli, Irak

\section{Introduction}

The global prevalence of HBV infection in the general population was $3.5 \%$ in 2015 . This means that around 257 million persons live with an HBV infection. The prevalence of HBV infection is highest in the African (6.1\%) and Western Pacific regions (6.2\%). The proportion of persons living with chronic HBV infection remains high, particularly among those born before the hepatitis B vaccine became available. There are around 65 million chronically infected women of childbearing age who might transmit HBV to their babies. ${ }^{1}$

The delivery of health care services has the potential to transmit HBV infection to health care workers (HCWs). Outbreaks of HBV infection have occurred in health care settings, primarily as a result of unsafe injection practices including reuse of needles, finger-stick devices, and syringes; and other lapses in infection control. HCWs should receive hepatitis $B$ vaccine as they have a considerable risk of exposure to blood during their work. Anti-HBs testing should be performed to HCWs whose work involve exposure to blood or bodily fluids, after the third dose of vaccination to document immunity. ${ }^{2}$ The prevalence of HBV infection (HBsAg and/or anti-HBc) in Duhok governorate was $15.9 \%$ in 2011 with the highest prevalence of HBsAg among Iraqi governorates (3.6\%). ${ }^{3}$ A recent study revealed that $1.8 \%$ of patients undergoing elective surgical operations in Duhok were HBsAg positive. ${ }^{4}$

In the last few years, there has been a growing interest in HBV infection among HCWs in Duhok governorate. However, limited research has tackled this subject. ${ }^{5}$ This study was, therefore, carried out to determine the rates of protective anti-HBs levels and HBV infection among HCWs in Duhok city and their association with certain socio-demographic variables and occupational risk factors. 


\section{Method}

A cross-sectional study was conducted on HCWs in Duhok city from the $1^{\text {st }}$ of March 2014 through to the 20 ${ }^{\text {th }}$ of April 2015. A multistage stratified sampling technique method was adopted for this study. In the first step, a random sample of four public hospitals (Azadi General Hospital, Emergency Hospital, Maternity Hospital and Heevi Paediatric Hospital) and four specialized health centers (dental polyclinic complex, blood bank, public laboratory and renal dialysis center) was selected from health facilities in Duhok city. HCWs with more than six months of professional practice were included in the study. Only 1775 HCWs met the inclusion criteria of the study. The calculated sample size was 191, based on $5 \%$ precision, an anti-HBs prevalence of $85 \%$ and a $95 \%$ confidence interval. As multistage stratified sampling methods require a larger sample size to achieve the same precision, the calculated sample size then was multiplied by design effect, which is two in this study, making the sample size 382 HCWs. Furthermore, the sample size was increased to 504 HCWs to adjust for non-response or recording errors. The eligible HCWs were divided into eight professional groups, then a proportionate number of HCWs was selected from each group as follows: 108 from the physicians group, 225 from the nurses group, 68 from the laboratory group, 17 from the dentistry group, 21 from the radiology group, and 23 from the pharmacists group, as well as 21 technicians and 21 cleaning workers. The eligible subjects in each stratum were selected randomly by a systematic random sampling technique.

Data was collected by a direct interview using an specifically designed, close-ended questionnaire. The questionnaire was comprised of four main parts. The first part covered the sociodemographic and professional characteristics of the HCWs. The second part was about hepatitis B vaccination status (number of received doses and the date of the last dose). The third part was about the history of potential exposure to $\mathrm{HBV}$, including the history of surgical operations, dental surgery, blood transfusion, sharing of personal items and occupational exposure to blood and/or its components (needle stick injury, cut injury or direct mucocutaneous exposure). The last part was about the history of previous testing for the anti-HBs level.

ELISA was used for detection of HBsAg, anti-HBc and anti-HBs by using commercially available Biokits (BarcelonaSpain via fully automated Flex Biotech analysis). HBsAg positive serologic samples were further tested for detection of the HBeAg and anti-HBe using an electrochemiluminescence immunoassay (Roche Diagnostic Gmbh, D-68298 Mannheim, Germany). Laboratory testing for HBV serological markers was carried out in the virology laboratory of prevention directorate in Duhok city. Serum anti-HBs level of $\geq 10 \mathrm{mIU} / \mathrm{ml}$ was considered seroprotective according to manufacturer's instructions.

The study was approved by the research ethics committee of the authors' institution, and a written informed consent was obtained from each participant. Chisquare test, odds ratio (OR) with 95\% CI and binary logistic regression were used to test for association between categorical variables. A $p$ value of $\leq 0.05$ was considered as statistically significant.

\section{Results}

Of the 504 participants, 243 (48.2\%) were males, giving a male to female ratio of 0.93 : 1 . The age range of the participants was 2063 years with a mean age of \pm SD $32.05 \pm$ 7.85 years. Out of the total 504 HCWs, 303 $(60.1 \%)$ had received at least one dose of hepatitis B vaccine and 191 (38.0\%) were fully vaccinated (received three doses or more). Statistically significant differences were observed in the proportions of vaccination of the different profession groups $(p<0.001)$, with the highest proportion of vaccinations among the dentistry group (82.4\%) and the lowest among cleaning workers $(9.5 \%)$. The odds of receiving vaccination for HCWs who have spent 6-10 years in practice was $39.0 \%$ 
lower than the odds of those who have spent $\leq 5$ years in practice $(\mathrm{p}=0.03)$. Details are shown in Table 1. Out of the 303 HCWs who had been vaccinated with the hepatitis B vaccine, 57 (18.8\%) had received one dose, 55 (18.2\%) had received two doses, and 191 (63.0\%) had received three doses or more (shown in Table 4). Twenty nine of the 191 fully vaccinated HCWs (15.2\%) did not develop protective anti-HBs level. Only $65(21.5 \%)$ of the 303 who had ever been vaccinated with $\mathrm{HB}$ vaccine, had their blood tested for the anti-HBs level.

The reported post-vaccination testing among those who received one dose, two doses or three doses or more were $15.8 \%, 9.1 \%$ and $27.6 \%$, respectively. The highest proportion (75.0\%) of postvaccination anti-HBs testing in the fully vaccinated HCWs was among the radiology group (Table 2).

Of the total 504 participants, only $253(50.2 \%)$ had been exposed to blood or bodily fluids. The reported proportions of occupational exposures to blood and/or its components; needle stick injuries, cut injuries and mucocutaneous exposure; were $40.3 \%, 6.9 \%$ and $2.8 \%$ respectively, with an overall proportion of $50 \%$. All participants with the history of such exposures did not seek post-exposure prophylaxis (PEP) and none of them had received HBIG. History of surgical interventions, dental interventions and blood transfusions were reported by $39.5 \%, 50.2 \%$ and $6.5 \%$ of participants, respectively. Sharing of personal hygiene items (razors, toothbrushes and nail clippers) was reported by $44.2 \%$ of participants. Details are shown in Table 3.

The prevalence of protective antiHBs levels among vaccinated HCWs was positively associated with the number of received doses $(p<0.001)$, and vaccination under 40 years of age $(p=0.03)$. The rate was shown to significantly $(p=0.006)$ decline with age, particularly for those in their $6^{\text {th }}$ or $7^{\text {th }}$ decades of life with no significant sex variation (Table 4).
Only $9(1.8 \%)$ subjects out of the total HCWs were HBsAg positive and 46 (9.1\%) were anti-HBc positive. The prevalence of overall HBV infections (positive HBsAg and/or anti-HBc) was 9.5\%. Out of the nine positive HBsAg subjects, only one $(11.1 \%)$ was HBeAg positive and seven (77.8\%) were anti-HBe positive. One subject had neither HBeAg nor anti-HBe. HBV infection was significantly associated with occupational exposure to blood $(\mathrm{OR}=2.38$; $95 \% \quad \mathrm{CI}=1.26-4.50)$ and dental interventions $(\mathrm{OR}=2.36$; 95\% $\mathrm{CI}=1.25 \quad$ 4.46) as shown in Table 5.

\section{Discussion}

In this study, the proportion of fully vaccinated HCWs and those who received at least one dose were $38.0 \%$ and $60.1 \%$, respectively, indicating that the coverage rates of vaccination are relatively low. Studies from different countries have shown different rates of HCWs who have received the recommended doses of hepatitis B vaccine. For example, this rate was $39.8 \%$ in Sweden, ${ }^{6}$ 37.2\% in Pakistan, 7 55.8\% in Turkey ${ }^{8}$ and $19.9 \%$ in South Africa. ${ }^{9}$ The study from Sweden in 2006 reported that the proportion of fully vaccinated HCWs and those who received at least one dose were $40.0 \%$ and $79.0 \%$, respectively. ${ }^{6}$ The significantly lower proportion of vaccination among cleaning workers can most likely be attributed to the low perception of HBV infection risk among cleaning workers.

The worldwide level of the poor immune response to $\mathrm{HBV}$ vaccination in any population is around $5-10 \% .10,11$ In this study, $15.2 \%$ of fully vaccinated HCWs did not develop a protective level of anti- HBs, which is slightly higher than global levels. 
Table 1. Binary logistic regression predicting likelihood of vaccination status by sex, age group, profession group and duration of practice

\begin{tabular}{|c|c|c|c|c|c|}
\hline Variable & $\begin{array}{c}\text { Total } \\
\text { No. }\end{array}$ & $\begin{array}{c}\text { Vaccinated } \\
\text { No. (\%) }\end{array}$ & $\mathbf{O R}$ & $95 \% \mathrm{CI}$ & $p$ value \\
\hline \multicolumn{6}{|l|}{ Sex } \\
\hline Male (ref.) & 243 & $142(58.4)$ & 1 & & \\
\hline Female & 261 & $161(61.7)$ & 1.29 & $0.88-1.90$ & 0.19 \\
\hline \multicolumn{6}{|l|}{ Age groups (years) } \\
\hline $20-29$ & 226 & $136(60.2)$ & 2.81 & $0.79-10.07$ & 0.11 \\
\hline $30-39$ & 189 & $113(59.8)$ & 2.70 & $0.79-9.20$ & 0.11 \\
\hline $40-49$ & 73 & $45(61.6)$ & 1.84 & $0.56-5.10$ & 0.31 \\
\hline$\geq 50$ (ref.) & 16 & $9 \quad(56.3)$ & 1 & & \\
\hline \multicolumn{6}{|l|}{ Profession group } \\
\hline Physicians & 108 & $79(73.1)$ & 28.75 & $6.24-132.53$ & $<0.001$ \\
\hline Nurses & 225 & $121(53.8)$ & 11.30 & $2.54-50.24$ & 0.01 \\
\hline Laboratory workers & 68 & $49(72.1)$ & 26.79 & $5.61-127.90$ & $<0.001$ \\
\hline Dentistry & 17 & $14(82.4)$ & 48.76 & $7.03-338.23$ & $<0.001$ \\
\hline Radiology & 21 & $10(47.6)$ & 9.62 & $1.73-53.40$ & 0.01 \\
\hline Pharmacy & 23 & $17(73.9)$ & 28.49 & $5.01-162.03$ & $<0.001$ \\
\hline Technicians & 21 & $11(52.4)$ & 12.52 & $2.26-69.22$ & 0.04 \\
\hline Cleaning workers (ref.) & 21 & $2(9.5)$ & 1 & & \\
\hline \multicolumn{6}{|l|}{ Duration of practice (years) } \\
\hline$\leq 5$ (ref.) & 267 & $162(60.7)$ & 1 & & \\
\hline $6-10$ & 125 & $66(52.8)$ & 0.61 & $0.39-0.96$ & 0.03 \\
\hline $11-15$ & 55 & $35(63.6)$ & 1.05 & $0.56-1.95$ & 0.89 \\
\hline $16-20$ & 24 & $16(66.7)$ & 1.21 & $0.49-3.03$ & 0.68 \\
\hline$>20$ & 33 & $24(72.7)$ & 1.75 & $0.76-4.01$ & 0.19 \\
\hline Total & 504 & $303(60.1)$ & ---- & --- & --- \\
\hline
\end{tabular}


Table 2. Post-vaccination testing of anti-HBs level among HCWs who received three or more doses by profession group $(\mathrm{n}=191)$

\begin{tabular}{lcc}
\hline Profession group & $\begin{array}{c}\text { No. of fully vaccinated HCWs } \\
(\geq \mathbf{3} \text { doses) }\end{array}$ & $\begin{array}{c}\text { Post-vaccination } \\
\text { anti-HBs testing } \\
\text { No. (\%) }\end{array}$ \\
\hline Physicians & 52 & $18(34.6)$ \\
Nurses & 83 & $16(19.3)$ \\
Laboratory workers & 27 & $9(33.3)$ \\
Dentistry & 7 & $1(14.3)$ \\
Radiology & 4 & $3(75.0)$ \\
Pharmacy & 13 & $4(30.8)$ \\
Technicians & 5 & $0(0.0)$ \\
Cleaning workers & 0 & $0(0.0)$ \\
Total & 191 & $51(26.7)$ \\
\hline
\end{tabular}

Table 3. Potential exposure to HBV infection $(n=504)$

\begin{tabular}{lc}
\hline Type of exposure* $^{*}$ & $\begin{array}{c}\text { Yes } \\
\text { No. (\%) }\end{array}$ \\
\hline Occupational exposure to blood and /or its components & $252(50.0)$ \\
$\quad$ Needle-stick injury & $203(40.3)$ \\
$\quad$ Cut injury & $35(6.9)$ \\
$\quad$ Mucocutaneous exposure & $14(2.8)$ \\
Surgical intervention & $199(39.5)$ \\
Dental intervention & $253(50.2)$ \\
Blood transfusion & $33(6.5)$ \\
Sharing personal items & $223(44.2)$
\end{tabular}

*More than potential exposure was reported by some participants.

**Including razors, toothbrushes and nail clippers. 
Table 4. Prevalence of protective anti-HBs levels among vaccinated HCWs by number of vaccination doses, age and sex of HCW and age at vaccination $(n=303)$

\begin{tabular}{|c|c|c|c|}
\hline Variables & $\begin{array}{l}\text { No. of HCWs tested } \\
\text { No. }(\%)\end{array}$ & $\begin{array}{c}\text { HCWs with protective anti- } \\
\text { HBs } \\
\text { No. ( } \%)\end{array}$ & p value \\
\hline \multicolumn{4}{|c|}{ Vaccination doses } \\
\hline 1 dose & 57 (18.8) & 17 (29.8) & \\
\hline 2 doses & 55 (18.2) & 37 (67.3) & $<0.001$ \\
\hline$\geq 3$ doses & $191(63.0)$ & $162(84.4)$ & \\
\hline \multicolumn{4}{|l|}{ Age group } \\
\hline $20-29$ & $136(44.9)$ & $102(75.0)$ & \multirow{4}{*}{0.006} \\
\hline $30-39$ & $113(37.3)$ & 83 (73.5) & \\
\hline $40-49$ & 45 (14.8) & $30(66.7)$ & \\
\hline$\geq 50$ & $9 \quad(3.0)$ & 1 (11.1) & \\
\hline \multicolumn{4}{|l|}{ Sex } \\
\hline Male & $142(46.9)$ & 99 (69.7) & \multirow{2}{*}{0.62} \\
\hline Female & $161(53.1)$ & 117 (72.7) & \\
\hline \multicolumn{4}{|c|}{ Age at vaccination } \\
\hline$<40$ & 249 (82.2) & $185(74.3)$ & \multirow{2}{*}{0.03} \\
\hline$\geq 40$ & 54 (17.8) & 31 (57.4) & \\
\hline Total & $303(100.0)$ & $216(71.3)$ & \\
\hline
\end{tabular}

This high rate of poor response could be attributed to variations in vaccine potency, poor maintenance of cold chain system and/or host-related factors. Vaccinated HCWs, therefore, should be aware of their post-vaccination anti-HBs status. Data from a large hospital in Dublin, Ireland, revealed that $93.0 \%$ of nurses had their anti-HBs levels checked on completion of the immunization. ${ }^{12}$ In this study, the proportion of post-vaccination anti-HBs testing among fully vaccinated HCWs was only $26.7 \%$, with highest percentage among the radiology group (75.0\%), while it was zero among technicians and cleaning workers. It's possible that technicians and cleaning workers have fewer opportunities to gain adequate knowledge about the benefits of anti-HBs testing. Dentistry HCWs are at higher risk for acquiring HBV infection (more than 50\% possible rate of exposure) than other professional groups such as pharmacy or radiology workers. However, only $14.3 \%$ of them had checked their anti-HBs status compared to the higher proportions of radiology and pharmacy 
Table 5. Prevalence of HBs Ag and overall HBV infection by certain potential exposures $(n=504)$

\begin{tabular}{|c|c|c|c|c|c|}
\hline \multirow{2}{*}{$\begin{array}{l}\text { Type of potential } \\
\text { exposure }\end{array}$} & \multirow{2}{*}{ Total } & \multicolumn{2}{|c|}{ Positive HBs Ag } & \multicolumn{2}{|c|}{ Overall HBV infection } \\
\hline & & No. (\%) & OR (95\% CI) & No. $(\%)$ & OR (95\% CI) \\
\hline $\begin{array}{l}\text { Surgical } \\
\text { intervention }\end{array}$ & 199 & $4(2.0)$ & $1.23(0.33-4.64)$ & $22(11.1)$ & $1.33(0.73-2.43)$ \\
\hline $\begin{array}{l}\text { Dental } \\
\text { intervention }\end{array}$ & 253 & $7(2.8)$ & $3.54(0.73-17.22)$ & $33(13.0)$ & $2.36(1.25-4.46)$ \\
\hline $\begin{array}{l}\text { Blood } \\
\text { transfusion }\end{array}$ & 33 & $0(0.0)$ & & $3(9.1)$ & $0.95(0.28-3.23)$ \\
\hline $\begin{array}{l}\text { Occupational } \\
\text { exposure to blood } \\
\text { and/or its } \\
\text { components }\end{array}$ & 252 & $7(2.8)$ & $3.57(0.73-17.36)$ & $33(13.1)$ & $2.38(1.26-4.50)$ \\
\hline $\begin{array}{l}\text { Sharing personal } \\
\text { items* }\end{array}$ & 223 & $7(3.1)$ & $4.52(0.93-21.98)$ & $24(10.8)$ & $1.29(0.72-2.34)$ \\
\hline
\end{tabular}

*Including razors, toothbrushes and nail clippers

The protective anti-HBs ranges induced by one dose, two doses or three doses are reported to be $20-30 \%, 75-80 \%$, and $90-95 \%$, respectively. ${ }^{13}$ In this study, the protective anti-HBs prevalence rates among who received one dose, two doses or three doses or more were around $30.0 \%, 67.0 \%$ and $85.0 \%$, respectively, with an overall prevalence of $71 \%$. These findings agree with those of another study conducted in Duhok in 2015, where the rate of protective anti-HBs among fully vaccinated HCWs was $85.0 \% .^{5}$

Advanced age negatively affected the seroconversion rate regardless of the patient's status. ${ }^{14,15}$ Several studies have shown that when the age at vaccination is older than 40 years, the rate of protective anti-HBs is fewer. ${ }^{13,16} \mathrm{~A}$ similar finding was revealed by our study. This study further revealed a significant decline in the prevalence of protective anti-HBs with advancing age among the vaccinated HCWs, irrespective of age at vaccination. This finding is in agreement with two other studies on the subject.17,18 Contrary, to our findings, Hussien in Duhok reported a significantly higher prevalence of protective anti-HBs among female HCWs. ${ }^{5}$ However, an Iranian study revealed a non-significant sex variation. ${ }^{18}$

Administration of post exposure passive-active PEP, using HBIG and hepatitis $B$ vaccine, and active PEP with hepatitis $B$ vaccine alone are both very helpful in preventing HBV infection. ${ }^{19}$ Our study revealed that none of the respondents who had a history of exposure have received PEP. This finding is probably due to lack of a PEP policy in the health care facilities of Duhok, although, occupational exposure to blood and other body fluids at work was reported at $50.0 \%$. This finding highlights the necessity for PEP for HCWs in Duhok. A study in Nepal on medical school students in 2014 showed that, following exposure, only $11.4 \%$ received PEP and $19.5 \%$ had postexposure serological testing. ${ }^{20}$

The overall exposure to HBV infection is an important indicator of the epidemiological pattern of the disease; all 
persons having tested positive for $\mathrm{HBsAg}$ and/or anti-HBc are regarded as having been exposed to an HBV infection. ${ }^{21}$ The CDC estimates that the annual risk of HBV infection is between $0.6 \%$ to $2.0 \%$ for HCWs. ${ }^{19}$ Studies in different parts of the world showed that the prevalence of HBsAg among HCWs varies between 0 and $20.0 \%{ }^{20}$ Geographical variations in the prevalence of HBsAg might be attributed to differences in environmental exposure, cultural and social habits, and hepatitis $B$ vaccination coverage rates. ${ }^{23}$ The prevalence of HBsAg among HCWs in this study was $1.8 \%$, which is much lower than those reported among HCWs in other governorates of Iraq. The prevalence of HBsAg was 5.4\% in Baghdad in 1995 to $1998,246.6 \%$ in Mosul in 1987,25 and 3.8\% in $\mathrm{Al}$-Tameem in 2001.26 The decline in the prevalence of HBsAg positivity in Iraq might be partially explained by increased HCWs' awareness about transmission of HBV and better hygienic measures adopted in the late 1970s and early 80s (e.g. the use of disposable syringes and intravenous sets) in addition to the introduction of the hepatitis $B$ vaccination for infants and high risk groups. The prevalence of overall HBV infection (positive HBsAg and/or anti-HBc) in our study was $9.5 \%$. This rate is slightly higher than the one reported in Turkey nursing students $(7.5 \%) .{ }^{27} \mathrm{~A}$ much higher rate (57.0\%) was reported in Sudan in 2012.28

There was no significant association of prevalence of HBV infection with history of surgical intervention and history of blood transfusion in our study. This finding might be attributed to rigorous screening of donated blood at blood banks and preoperative screening of majority of patients who require elective surgical interventions at health care facilities of Duhok. However, HCWs with the history of dental interventions were more likely to have HBV infections, which might be attributed to the low standards of sterilization in dental care facilities. Occupational exposure to blood was also significantly associated with increased risk of HBV infection; HCWs with a history of exposure were twice as likely to be HBV positive than those without such exposure.

\section{Conclusion}

HCWs are highly susceptible to HBV infections. The rate of protective anti-HBs levels among fully vaccinated HCWs is acceptable. However, vaccination coverage and post-vaccination testing are still low and there is no post-exposure prophylaxis policy in Duhok health care facilities.

\section{References}

1. WHO. Global Hepatitis Report 2017. Available at: http://apps.who.int/iris/bitstream/106 65/255016/1/9789241565455eng.pdf?ua=1. Accessed July 10, 2018.

2. CDC. Health care settings and viral hepatitis, Division of Viral Hepatitis and National Center for HIV/AIDS, Viral Hepatitis, STD, and TB Prevention 2008. Available at: http://www.cdc.gov/hepatitis/Settings/ Health careSettings.htm. Accessed March 3, 2017.

3. Merza MA, Hassan WM, Muhammad AS. Frequency of HBV and HCV among patients undergoing elective surgery in a tertiary care referral hospital in Duhok, Iraqi Kurdistan. JMSCR 2014;2(7):1810-1815.

4. Saleh MA, Ali R, Omer AR, Atallah M, AlSalmani AM, Karrem SA. Hepatitis B seroprevalence in ten Iraqi governorates. Al- Mustansiriya J Sci 2011;1(22):220-222.

5. Szmuness W, Stevens CE, Zang EA, Harley EJ, Kellner A. A controlled clinical trial of the efficacy of the hepatitis $B$ vaccine (Heptavax B): a final report. Hepatology 1981;1(5):377-385.

6. Dannetun E, Tegnell A, Torner A, Giesecke J. Coverage of hepatitis B vaccination in Swedish healthcare workers. J Hosp Infect 2006;63(2):201204.

7. Mengal HU, Howteerakul N, Suwannapong N, Rajatanun T. Factors relating to acceptance of hepatitis $B$ virus vaccination by nursing students in 
a tertiary hospital. Pakistan J Health Popul Nutr 2008;26(1):46-53.

8. Hatipoglu CA, Yetkin MA, Ergin F, Ipekkan K, Erdinc FS, Bulut $\mathrm{C}$, et al. Vaccination of healthcare workers against hepatitis $B$ virus in a teaching hospital. J Hosp Infect 2007;67(2):200202.

9. Burnett RJ, Francois G, Mphahlele MJ, Mureithi JG, N Africa P, Satekgea MM, et al. Hepatitis $B$ vaccination coverage in healthcare workers in Gauteng Province, South Africa. Vaccine 2011;29(25):4293-4297.

10. Floreani A, Baldo V, Cristofoletti M, Renzulli G, Valeri A, Zanetti C, et al. Long-term persistence of anti-HBs after vaccination against $\mathrm{HBV}$ : an 18 year experience in health care workers. Vaccine 2004;22(5-6):607-610.

11. McGrane J, Staines A. Nursing staff knowledge of the hepatitis B virus including attitudes and acceptance of hepatitis B vaccination: development of an effective program. AAOHN J 2003;51(8):347-352.

12. Jack AD, Hall AJ, Maine N, Mendy M, Whittle HC. What level of hepatitis B antibody is protective? J Infect Dis 1999;179(2):489-492.

13. Hussien NR. Prevalence of HBV, HCV and HIV and anti-HBs antibodies positivity in health care workers in departments of surgery in Duhok city, Kurdistan Region, Iraq. Int J Pure Appl Sci Technol 2015;26(2):70-75.

14. Zeeshan $M$, Jabeen $K$, Ali $A N$, et al. Evaluation of immune response to hepatitis B vaccine in health care workers at a tertiary care hospital in Pakistan: an observational prospective study. BMC Infect Dis 2007;7:120.

15. DaRoza G, Loewen A, Djurdjev 0, et al. Stage of chronic kidney disease predicts seroconversion after hepatitis B immunization: earlier is better. Am J Kidney Dis 2003;42(6):1184-1192.

16. Hashemi B, Mahdavi M, Abbasi M, Hosseini SM, Hatmi Zinat N, Ahmadi F. Efficacy of HBV vaccination in various stages of chronic kidney disease: is earlier better? Hepat Mon 2011;11(10):816-820.

17. van der Sande MA, Waight P, Mendy M, et al. Long-term protection against carriage of hepatitis B virus after infant vaccination. $\mathrm{J}$ Infect Dis 2006;193(11):1528-1535.

18. Alavian SM, Mahboobi N, Mahboobi N. Anti-HBs status and some of its associated factors in dental health care workers in Tehran University of Medical Sciences. Hepat Mon 2011;11(2):99102.

19. CDC. Recommendations and Reports Appendix B: Immunization Management Issues 2005;54(RR16);27-30.

20. Bhattarai S, Pradhan PM, Lama S, Rijal S. Hepatitis B vaccination status and needle stick and sharps-related injuries among medical school students in Nepal: a cross-sectional study. BMC Res Notes 2014;7:774.

21. Heymann DL. Control of communicable diseases manual. $19^{\text {th }}$ ed. Washington: American Public Health Association, 2008. p. 284-293.

22. Mast EE, Margolis HS, Fiore AE, et al. A comprehensive immunization strategy to eliminate transmission of hepatitis B virus infection in the United States: recommendations of the Advisory Committee on Immunization Practices (ACIP). Part 1: immunization of infants, children, and adolescents. MMWR Recomm Rep 2005;54(RR-16):1-31.

23. Leuridan E, Van Damme P. Hepatitis B and need for a booster dose. Clin Infec Dis 2011;53(1):68-75.

24. Al-Mashhadani J, Al-Hadithi T, Al-Diwan J, Omer AR. Prevalence of hepatitis B serological markers among health care workers in Baghdad, Iraq. JABMS 2008;9(3):17-22.

25. Mohammed HY. Prevalence of hepatitis $B$ and delta viral infections among hospital personnel in Mosul. MSc. thesis, College of Medicine, Mosul University, Iraq; 1987. 
26. Khadir MA, Ismail AM, Tahir $\mathrm{S}$. Serosentivity of hepatitis B and C among different groups of population in AlTameem province. Iraqi J Comm Med 2001;14:21-24.

27. Irmak Z, Ekinci B, Akgul AF. Hepatitis B and $\mathrm{C}$ seropositivity among nursing students at a Turkish university. Int Nurse Rev 2010;57(3):365-369.

28. Ahmed ET, Ali IO, Elkhidir IM, Ali BA, Ali AM. Socio-demographic characteristics of health care workers and HBV infection in public teaching hospitals in Khartoum State, Sudan. Global J Health Sci 2012;4(4):37-41. 